\author{
Данијела Ђоровић \\ Универзитет у Београду - Филозофски факултет \\ ddjorovi@f.bg.ac.rs \\ Слађана Станојевић \\ Универзитет у Крагујевцу - Филолошко-уметнички факултет \\ sladjana.stanojevic@filum.kg.ac.rs
}

\title{
СЕМАНТИЧКЕ ВРЕДНОСТИ ДЕМИНУТИВА У ИТАЛИЈАНСКИМ КЮИЖЕВНИМ ТЕКСТОВИМА РЕНЕСАНСЕ И БАРОКА
}

\begin{abstract}
Апстракт: Богат, разуђен и веома продуктиван систем деминутива у италијанском језику чест је предмет лингвистичких и лингвопрагматичких проучавања која се најчешће спроводе из синхронијске перспективе и на некьижевном језичком материјалу. У овом раду испитују се семантичке вредности деминутива с нагласком на њихова конотативна значена у италијанском књижевном језику касне ренесансе, маниризма и барока. За потребе истраживања коришћен је дијахронијски морфолошки корпус MIDIA (Morfologia dell'Italiano in DIAcronia), односно његов поткорпус који обухвата књижевне текстове настале између 1533. и 1691. године. Резултати истраживања показују да семантичке вредности испитиваних деминутива не само да не могу бити интерпретиране искључиво у денотативном кључу, већ да их карактеришу разноврсне конотативне и асочијативне компоненте значења потекле од различитих, негативно или позитивно обојених вредносних судова, имплицираних у употреби овде разматраних деминутива.
\end{abstract}

Кључне речи: деминутиви, семантичке вредности, евалуативна морфологија, конотативна значења, италијански језик.

\section{1. Увод}

У италијанском језику творба речи субјективне процене представља посебан тип суфиксације којом се значење речи из основе суштински не мења, већ се мења само неки њен вид, као што је квалитет, квантитет, став говорника. ${ }^{1}$ Деминутиви, као један од најчешће и најшире разматраних видова алтерације значења речи у том смислу, били су предмет истраживања

${ }^{1}$ Мила Самарџић, Поглед на речи, Београд, Филолошки факултет Универзитета у Београду, 2011, стр. 118. 
још у деветнаестом веку ${ }^{2}$, а последње деценије XX века обележио је велики број студија у којима се овај феномен испитује из различитих перспектива, са аспекта дијахроније или синхроније, морфологије, семантике, с фокусом на појединачне деминутивне суфиксе или на компаративно сагледавање формирања деминутива у појединим језицима, као и из угла стилистике, морфопрагматике и морфосемантике. ${ }^{3}$ Посебну област истраживања чини проучавање деминутива употребљених у одређеном књижевном жанру, код појединих аутора или у неком периоду развоја књижевног језика. ${ }^{4}$

Ово питање се у литератури разматра у оквиру експресивне или

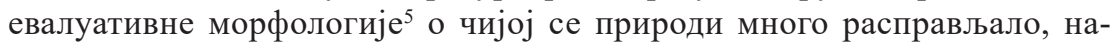
рочито од када је Скализе у својој Генеративној морфологији 6 поставио хипотезу да евалуативи показују неке одлике деривације, неке пак флексије, а да поједине одлике не могу бити сврстане ни у деривационе ни у флексионе. Бројна истраживања бавила су се овом темом, те не чуди што су овако посматрану морфологију неки аутори дескриптивно назвали и „трећом морфологијом”, насупрот флексивној и деривационој. Кад је реч о романским језицима, ипак, преовлађује мишљење да је реч о подврсти деривационе морфологије.

Главни предмет проучавања ове области јесу евалуативни афикси те се често разматрање евалуативне морфологије у литератури и поистовећује са истраживањем њихових одлика. Према Грандију ову врсту афикса неоп-

${ }^{2}$ George Cornewall Lewis, On English Diminutives, The Philological Museum, 1832, стр. 679-86; Herbert Coleridge, "On diminutives in let”, Transactions of the Philological Society, 4 (1), 1857, стр. 93-115.

${ }^{3}$ Mary R. Haas, "The Expression of the Diminutive”. In DIL, A.S. (ed.). Language, culture and history: essays by Mary R. Haas, Stanford, Stanford University Press, 1978, стр. 82-88; Anna Wierzbicka, "Diminutives and depreciatives: Semantic representation for derivational categories", Quaderni di semantica, 5(1), 1984, стр. 123-30; Bronislava Volek, Emotive signs in language and semantic functioning of derived nouns in Russian. Amsterdam, J. Benjamins, 1987; Pamela Munro, "Diminutive syntax", In W. Miller (ed.), A Festschrift for Mary R. Haas, The Hague, Mouton, 1988, стр. 539-56; Wolfgang U. Dressler, Lavinia Merlini Barbaresi, "Italian Diminutives as NonPrototypical Word Formation”, Natural Morphology-Perspectives for the Nineties, 1992, стр. 21-29; Wolfgang U. Dressler, Lavinia Merlini Barbaresi, Morphopragmatics: diminutives and intensifiers in Italian, German, and other Languages, Berlin-New York, Mouton, 1994; Dan Jurafsky, "Universal tendencies in the semantics of the diminutive", Language, 1996, стр. 533-578.

${ }^{4}$ Emilio Náñez Fernández, El diminutivo. Historia y funciones en el español clásico y moderno. Madrid: Editorial Gredos, S. A., 1973; Marina Dossena, "Vocative and diminutive forms in Robert Louis Stevenson's fiction: A corpus-based study". Journal of English Studies, 12(2), 2012, стр. 1-17.

${ }^{5}$ Olga Steriopolo, "Form and function of expressive morphology: A case study of Russian". In Russian Language Journal, 2009, vol. 59, стр. 149-194; Nicola Grandi, "Matrici tipologiche vs. tendenze areali nel mutamento morfologico. La genesi della morfologia valutativa in prospettiva interlinguistica", Lingue e linguaggio, 2 (1), 2003, стр. 105-146; Nicola Grandi, The place of evaluation within morphology. Edinburgh handbook of evaluative morphology, 2015, стр. 75-90.

${ }^{6}$ Sergio Scalise, Generative morphology, Dordrecht, Foris, 1984.

${ }^{7}$ Nicola Grandi, The place of evaluation within morphology, нав. дело, стр. 75-77. 
Данијела Ђоровић, Слађана Станојевић, Семантичке вредности деминутива ...

ходно карактерише неутралност категорија, односно чињеница да њихово додавање не доводи до промене категорије којој основна реч припада. Оно што се пак мења јесте семантичко пуњење речи, али само када шири контекст дозвољава такву промену путем морфолошке модификације основне речи. Таква промена је искључиво парцијална, будући да основном семантичком значењу речи додаје информације о гледишту говорника у односу на комуникативну ситуацију у којој се налази. ${ }^{8}$ Централна позиција у изучавању евалуативне морфологије припада управо деминутивима, због продуктивности и богатства значења које поседују.

Овај рад бави се семантиком деминутива у дијахронијском књижевном контексту, док су истраживања семантичких вредности деминутива углавном феномен посматрала у синхронијској перспективи и на језичком материјалу који није ексцерпиран из књижевних дела.

\section{2. Денотативне и конотативне особености значења деминутива}

Деминутиви имају два основна аспекта значења: денотативни (где је главна одлика сићушност, у англосаксонској литератури обично позната као smallness) и конотативни, који рефлектује позитивни или негативни став говорника према референту исказаном деминутивном лексемом. То значи да се семантичка вредност деминутива не може свести на претходно поменуту денотацију сићушности, већ може да упућује на неке контекстуалне, ванјезичке елементе. Метафоричким проширењем одлике „сићушности” може се, на пример, додати и одлика „неважности” у сет значења неког деминутива. Денотативна и конотативна компонента у значењу деминутива могу бити заступљене у различитој мери, а може се и активирати само једно значење у датом контексту. Суфикси којима се граде деминутиви, као и остали суфикси, по мишљењу Шпицера, представљају за језик оно што је у музици кључ. ${ }^{9}$ Теоријско-лингвистичка разматрања комбинују се стога са прагматичким, стилистичким, социолингвистичким, како би анализа семантике деминутива била потпуна.

Питање прототипског значења деминутива било је предмет интересовања проучавалаца и у контексту дијахронијских истраживања у претходна два века. ${ }^{10}$ Ролфс, на пример, сматра да је основно значење деминутива везано за исказивање сличности, припадања или особине, из чега се непо-

\footnotetext{
${ }^{8}$ Grazia Crocco Galèas, "Diminutives within the theory of morphopragmatics", Working Papers in Linguistics, Thessaloniki, Aristotle University, 2004, стр. 6.

${ }^{9}$ Leo Spitzer, Italienische Kriegsgefangenenbriefe: Materialien zu einer Charakteristik der volkstümlichen italienischen Korrespondenz, P. Hanstein, 1921, стр. 201-202.

${ }^{10}$ Paulina Biały, "On the priority of connotative over denotative meanings in Polish diminutives", Studies in Polish Linguistics, 8(1), 2013, стр 2.
} 
средно развија семантичка вредност негативне евалуације. ${ }^{11}$ Гранди ${ }^{12}$ пак поменута релациона значења повезује са потоњим формирањем семантичке вредности „сићушности”, која се развија када се за референте узимају жива бића: из значења „младо” развија се значење „мало”, што је последица перципиране блискости термина. ${ }^{13}$ Такво виђење потврђује Јурафски ${ }^{14}$ који за централну вредност деминутива узима семантичко-прагматичку везаност за интеракцију са децом из које произлази најпре значење „сићушности”, док се остала сродна значења из њега даље радијално шире метафоричким преношењем категорије величине у контекст значаја, моћи, пола и централности или маргиналности.

Питање семантичке, односно прагматичке природе значења деминутива такође је често у фокусу истраживача и може се објаснити имплементирањем правила историјског развоја значења. Наиме, свака семантичка промена неопходно полази од прагматичког контекста и тиче се процедуралног значења, а значењска вредност се може сматрати фиксираном тек након што достигне одређени ниво фреквентности употребе. ${ }^{15}$ Тако, на пример, Дреслер и Мерлини Барбарези ${ }^{16}$ истичу да повезаност деминутива са идејом деце може заправо бити последица прототипског значења неформалности или лежерности с којом се по правилу комуницира са децом, што није став са којим се слажу сви аутори. Неки, попут Јурафског, ${ }^{17}$ сматрају да је смер развоја обрнут, односно да из укорењености деминутива у интеракцији са децом проистиче семантичка вредност неформалности.

Још једна уобичајена карактеристика дијахронијског развитка значења тиче се тежње ка развоју све апстрактнијих, мелиоративних или пејоративних значења, неопходних за адекватно исказивање говорниковог виђења света. ${ }^{18}$ Та тежња савршено се поклапа са претходно описаним постепеним удаљавањем од прототипског и приближавањем конотативном значењу,

${ }^{11}$ Gerhard Rohlfs, Grammatica storica dell'italiano e dei suoi dialetti, vol. II, Sintassi e formazione delle parole, Torino, Einaudi, 1969, стр. 356-357.

${ }^{12}$ Nicola Grandi, "Matrici tipologiche vs. tendenze areali nel mutamento morfologico. La genesi della morfologia valutativa in prospettiva interlinguistica", нав. дело, стр. 13-14.

${ }^{13}$ Anna Wierzbicka, "Diminutives and depreciatives: Semantic representation for derivational categories", нав. дело, стр. 123-30.

${ }^{14}$ Dan Jurafsky, "Universal tendencies in the semantics of the diminutive", нав. дело, стр. 533-578.

${ }^{15}$ Grazia Crocco Galèas, "Diminutives within the theory of morphopragmatics", нав. дело, стр. 11.

${ }^{16}$ Wolfgang U. Dressler, Lavinia Merlini Barbaresi, "Italian Diminutives as Non-Prototypical Word Formation", нав. дело, стр. 25.

${ }^{17}$ Dan Jurafsky, "Universal tendencies in the semantics of the diminutive", нав. дело, стр. 535.

${ }^{18}$ Maïa Ponsonnet, "A preliminary typology of emotional connotations in morphological diminutives and augmentatives", Studies in Language. International Journal sponsored by the Foundation "Foundations of Language”, 42 (1), 2018, стр. 20. 
Данијела Ђоровић, Слађана Станојевић, Семантичке вредности деминутива ...

које у одређеним случајевима може кулминирати напуштањем оригиналног прототипског значења. ${ }^{19}$

\section{3. Перспективе дефинисања емоција у евалуативној морфологији}

У досадашњим истраживањима на тему семантичких вредности деминутива наишли смо на три основна проблема у поставци истраживања са аспекта евалуативне морфологије.

Први проблем тиче се терминолошке неуједначености. Наиме, различита истраживања користе различите термине за веома сличне, готово идентичне дефиниције емотивних стања која одређују конотативна значења. Недостатак консензуса и стандардизације у овом смислу отежава директно надовезивање на већ постојеће налазе. Тако рецимо, Галеас ${ }^{20}$ у својој класификацији спаја интимност и фамилијарност, а разиграност раздваја од контекста интеракције са децом и љубимцима, док их Понсоне ${ }^{21}$ испитује у оквиру исте категорије, али их одваја од вредности утехе и породичне рутине коју везује искључиво за прагматички контекст интеракције одраслих особа.

Други проблем везан је за висок ниво субјективности у дескрипцији семантичких пуњења, који није пропраћен одговарајућим разграничењима утемељеним у литератури, већ је, као што и сами аутори понекад наводе, заснован на личној интерпретацији. Добар пример јесте класификација коју је предложила Понсоне, ${ }^{22}$ у којој су комплетне дефиниције пружене само за вредности презира и саосећања, док су, на пример, дивљење и поштовање дефинисани релативно, као различити степени одобравања. ${ }^{23}$ Поред наведених, јавља се и проблем превелике уопштености категорија које нису даље довољно издиференциране према интензитету, а где се у истој групи могу наћи најразличитије вредности обично међусобно веома удаљене на вредносној скали. Понсоне ${ }^{24}$ у поље негативних вредности убраја само понизност, аутоиронију и презир, док је Бјали ${ }^{25}$ поред поменутог уврстила и аверзију, исмевање, подозривост, критику, дистанцираност, иронију и потцењивање. Разлози оваквог стања могу проистицати из различитости језичког материјала који је анализиран, односно типа коришћеног корпуса

${ }^{19}$ Paulina Biały, "On the priority of connotative over denotative meanings in Polish diminutives", Studies in Polish Linguistics, 8 (1), 2013, стр. 12.

${ }^{20}$ Grazia Crocco Galèas, "Diminutives within the theory of morphopragmatics", нав. дело, стр. 6.

${ }^{21}$ Maïa Ponsonnet, "A preliminary typology of emotional connotations in morphological diminutives and augmentatives", нав. дело, стр. 9.

${ }^{22}$ Исто, стр. 13.

${ }^{23}$ Исто, стр. 18.

${ }^{24}$ Исто, стр. 9.

${ }^{25}$ Paulina Biały, "On the priority of connotative over denotative meanings in Polish diminutives", нав. дело, стр. 6 . 
или његове припадности синхронијском или дијахронијском контексту, величине корпуса, као и циља рада.

На основу консултоване литературе, наша претпоставка била је да ће у корпусу за који смо се определили бити присутни примери позитивно и негативно конотираних значења деминутива, али и да ће бити потребно да се она унутар тих двеју основних категорија даље разврстају према интензитету значења. На основу прелиминарних резултата, установљено је да примера за једну од очекиваних категорија, која се тиче појма разиграности, неће бити, те је она искључена из каснијих верзија предлога категоризације. Највећи изазов при успостављању категорија и поткатегорија значења деминутива из нашег корпуса било је проналажење одговарајућих дефиниција и термина који би што прецизније разграничили предложене категорије, и то са што већим нивоом објективности. Потреба за додатним појашњењем дефиниција емоционалних значења мотивисана је одређеним недовољно јасним примерима дефинисања емоција у постојећој литератури. С тим у виду, приступило се претрази речника психологије, која није донела много резултата јер у поменутим речницима мали број речи којима се традиционално описују нама потребне категорије фигурира као психолошки термин. Стога се у коначној верзији категоризације прибегло консултовању општег речника српског језика.

У складу са свим горе наведеним, предложене категорије семантичких вредности деминутива биће у овом раду дефинисане на следећи начин. У оквиру категорије позитивних вредности разликоваћемо четири поткатегорије: (а) приврженост, виђену као интензивно осећање снажног допадања или наклоности према некој особи или предмету, било у породичном, било у романтичном контексту; (б) фамилијарност или интимност, односно осећај блискости у основи везан за породични контекст (према лат. familia) одакле се проширио на све везано за рутину, свакодневицу и неформалност, у складу са образложењем присности и неусиљености на којој се заснива повезана дефиниција Речника српског језика Матице српске; (в) саосећање, према дефиницији Речника психологије ${ }^{26}$ схваћено као осећај наклоности, сажаљења или разумевања који омогућава интерпретацију или оправдање поступака и/или осећања других и (г) дивљење, или осећање поштовања, цењености или симпатије према нечијим позитивним особинама.

У контексту негативног вредновања истичу се две основне вредности: (а) блажи негативни суд, попут задиркивања, схваћеног у најопштијем смислу као „збијање шала на туђи рачун”27 и (б) оштрија негативна оцена, као што су потцењивање и презир, према Речнику Матице српске дефинисан као „осећање и показивање крајњег омаловажавања према некоме или

\footnotetext{
${ }^{26}$ Artur Reber, Emili Reber, Rečnik psihologije. Beograd, Službeni glasnik, 2010.

${ }^{27}$ Мирослав Николић (ур.), Речник српскога језика, Нови Сад, Матица српска, 2011, стр.
} 369. 
Данијела Ђоровић, Слађана Станојевић, Семантичке вредности деминутива ...

нечему". ${ }^{28}$ Последња два термина здружена су јер, иако се субјективном суду може учинити да постоје разлике у интензитету, речници ове термине уводе као синониме.

\section{4. Конотативна значења деминутива у италијанским књижевним текстовима ренесансе и барока}

Предмет овде представљеног истраживања су деминутиви у италијанским књижевним текстовима 16. и 17. века. а основни циљ јесте утврђивање присуства конотативних значења. Основна претпоставка била је да ће пронађени примери имати примесе конотативних значења, односно да ће искључиво денотативна значења бити ретко присутна, будући да су примери преузети из контекста литерарне прозе. Како је истраживање спроведено у дијахронијском контексту, такође је очекивано да се присутна значења неће у потпуности поклапати са оним која су слична истраживања пронашла у синхронијском контексту.

За потребе овог истраживања коришћен је корпус MIDIA (Morfologia dell'Italiano in DIAcronia), односно поткорпус који сакупља текстове из периода између 1533. и 1691. године, из периода касне ренесансе, маниризма и барока. Консултовањем историјских граматика издвојени су следећи суфикси присутни у италијанском језику кроз његов историјски развој: -etto, -(u)olo, -ello, -ino, -uzzo, -otto, -one, -azzo, -accio, -uccio, -icci(u)olo, -ucolo, -acchiotto, -iciattolo. ${ }^{29}$ Претраживање је извршено појединачно за сваки деминутивни суфикс, и посебно за наставке мушког и женског рода, односно једнине и множине. Како би се утврдило присуство емоционалног значења почетно претраживање корпуса извршено је за сваки пример у оквиру контекста од 30 речи, а затим су консултовани интегрални текстови како би се потврдили почетни налази.

У корпусу је пронађено 80 различитих форми деминутива (од којих се поједини јављају и више пута) у 21 књижевном делу. Прво што се запажа јесте претежна груписаност деминутива у одређеном типу литерарне прозе, пријемчиве за присуство јаче емоционалне обојености. На пример, код ренесансног комедиографа и писца шаљивих прозних састава Аретина успели смо да утврдимо постојање чак 23 деминутива, док се код других аутора, попут Макијавелија може наћи свеукупно три примера. ${ }^{30}$

Примарна категоризација примењена у овом раду заснована је на дихотомији позитивне и негативне вредности конотативног значења. Опозиција двеју поменутих макрокатегорија присутна је у готово свим

${ }^{28}$ Исто, стр. 992.

${ }^{29}$ Maurizio Dardano, Pietro Trifone, La lingua italiana, Zanichelli, 1985, стр. 333-334; Giampaolo Salvi, Lorenzo Renzi, Grammatica dell'italiano antico, Bologna, Il mulino, 2010, стр. 1505.

${ }^{30}$ Почетно истраживање је укључивало и Макијавелијева дела, али је због занемарљивог броја примера закључено да нису релевантна за истраживање. 
истраживањима овог типа, али се запажа да је много већа пажња обично посвећена позитивном делу спектра значења. Такође треба нагласити да се поменуте макрокатегорије могу у појединим примерима преклапати. Такво преклапање значења може се довести у везу са типом књижевног текста у коме су примери нађени.

Примере прикупљене претраживањем корпуса покушали смо да сагледамо на основу увида у категорије конотативних значења присутне у литератури. Већ прелиминарно истраживање показало је да претходни предлози класификације семантичких вредности не могу бити примењени у потпуности у оквирима предвиђеним за ово истраживање. Стога се јавила потреба за прилагођавањем параметара за анализу у дијахронијском контексту у којем је истраживање укорењено, што ће бити илустровано у даљем току рада.

Како би се избегла прекомерна уопштеност категоризације у оквиру макрокатегорија позитивног и негативног суда покушали смо да формулишемо одговарајуће поткатегорије. У оквирима позитивне конотативне вредности то су (а) приврженост, (б) фамилијарност, (в) саосећајност и (г) дивљење. Први утисак који се стиче на основу увида у корпус јесте да деминутиви који припадају поткатегорији (а) за референте обично имају децу и младунчад, а као контекст се често јавља породично окружење, о чему сведоче следећи примери:

(1) [...] venne il dì; e levato il procuratoredellesuecorna, con molta allegrezza della sorella ottenne il nipotino; e lo condusse a lei che gli fece gran festa. (Pietro Aretino, Ragionamenti, II, $44^{31}$ )

(2) Onde fatta questa deliberazione trovò la figliuola e sì le disse: - Figliuola, il mio re m'ha fatto far comandamento che io gli mandi una de le mie figliuole la più bella, ma per qualche mio conveniente rispetto che ora non accade dirti, io vo' che tu sia quella che ci vada. (Matteo Maria Bandello, Novelle, I, II, 1)

(3) Il bambino adunque, diligentemente nodrito, sovente veniva alla madre, e levatosi in piedi, le poneva il grognetto e le zampette in grembo. (Giovan Francesco Straparola, Piacevoli notti, II, 1, 3)

(4) Soleno porta seco una squadra di fanciulli a cavallo per imparar la guerra, ed incarnarsi, come lupicini, al sangue; (Tommaso Campanella, La città del sole, 74)

Из примера (2) може се видети да се ово значење не јавља нужно искључиво у директном обраћању референту на кога се односи, односно са типичним хипокористичким значењем, већ и у неуправном говору, у ширем контексту нарације. Наредна два примера пак илуструју семантичку повезаност између деце и младунчади кроз употребу деминутива не само за

\footnotetext{
${ }^{31}$ Ознаке у примерима одговарају онима коришћеним у корпусу.
} 
Данијела Ђоровић, Слађана Станојевић, Семантичке вредности деминутива ...

успостављање опште ситуационе сличности (4), већ и за описивање делова тела референта (3).

Поред контекста фамилијарне привржености, јављају се и примери везани за романтичну љубав, који се генерално сматрају повезаним са претходном литерарном традицијом, а конкретно са пасторалним делима где је приступ љубави типично лудички ${ }^{32}$ као што је то случај у примеру (5). При том се мора поставити питање осећаја аутора за поменуту нијансу употребљене речи и свесности утицаја претходне традиције.

(5) Non so se a caso avesse inteso, vezose e delicate donne, come fu non è molto tempo in una nostra villa non guari lontano da la città, un pastore el quale essendosi innamorato ne la sua puerisia di una vaga e bella pastorella, e semplicemente secondo che natura l'insegnava a quella sovente discupriva, ed essendo vicini, ogni giorno si trovavano insieme a le pasture; e venendo a crescere, di giorno in giorno il loro amore s'andava aumentando. [...] Aveva quella fanciulletta così bel volto quanto mai a villana fussi veduto, due occhi lucidissimi, le chiome propio parevano un fino oro, la persona assai proporsionata, le carni quanto un sodo e candido alabastro. (Pietro Fortini, Le Giornate delle novelle dei novizi, XII, 1)

Поткатегорија (б) означена термином фамилијарност блиска је категорији (а), али у њој, за разлику од идеје привржености, афективни моменат произлази из рутине, уобичајености и интимне повезаности са преовлађујуће неживим елементима. Самим тим, није изненађујуће што се највећи број пронађених примера који припадају овој поткатегорији односи на локалитете који се доживљавају као блиски, услед честог посећивања и консеквентне емотивне обојености. Овакве семантичке вредности деминутива најбоље илуструју наредни примери:

(6) Dove il monte si sedea, era uno orticello al quale i rosai facevano muricciuolo, che avea la porticella di verghe di salci intrecciate con la sua chiave di legno: e in tutto un dì non so si saria nel suo seno trovato un sassolino, sì bene lo tenea mondo il romito. I quadretti dello orto, diviso da alcune belle viette, erano pieni di varie erbe: qua lattuche crespe e sode, là pimpinelle fresche e tenere; alcuni erano di aglietti che il compasso non ne potria né levare né porre; altri dei più bei cavoli del mondo; la nepitella, la menta, lo aneto, la magiorana e il prezzemolo aveano anche loro il luogo suo nel giardinetto, in mezzo del quale facea ombra un mandrolo di quelle grandi sanza pelo. E per alcuni viottoli correva acqua chiara che usciva di una vena fra pietruzze vive dal piede del monte, che zampillava fuora tra le erbette: e tutto il tempo che il romito rubava alle orazioni, spendea in nutrire l'orticello. Poco lunge da esso sta la chiesetta con il suo campanile di due campanelline; e la capanna attaccata al muro della chiesa, dove riposava. In questo paradisetto venia la dottora come io ti ho detto (Pietro Aretino, II, 36)

${ }^{32}$ Maïa Ponsonnet, "A preliminary typology of emotional connotations in morphological diminutives and augmentatives", нав. дело, стр. 17. 
(7) Altre dicevano che il Re averebbe più a sdegno l'atto della disobedienza, che se esse gli avessero fatto scampar via quanti fagiani e pernici egli si trovava avere ne' suoi boschetti e giardini. (Giulio Cesare Croce, Le sottilissime astuzie di Bertoldo, Proemio)

У примеру (6) сама учесталост употребе деминутива учинила би њихово денотативно значење редундантним, те је конотативна вредност једина могућа. ${ }^{33}$ Пример (7) је пак посебно интересантан због повезаности облика boschetto са петраркистичком традицијом. ${ }^{34}$

Неки од поменутих локалитета добијају конотативно значење јер су уроњени у контекст романтичне љубави или ласцивних алузија, што сведочи о одређеној мери преливања значења између различитих категорија, што се може запазити у примеру (8).

(8) E, andatesene insieme con li amanti più su in una certa cameretta molto comoda per una faccenda tale, e quinci amorosamente con sommo piacere di tutti e quatro adempirno e ' desideri loro e ivi con grandissimo diletto si sollazavano. (Pietro Fortini, Le Giornate delle novelle dei novizi, VIII, 62)

Како је већ напоменуто, није увек било лако разврстати примере у осмишљене поткатегорије, нарочито када су у питању приврженост с једне и фамилијарност, с друге стране. Тако, специфичну семантичку вредност носи следећи пример (9), за који се јавила дилема да ли га сврстати у поткатегорију (а) или (б). Ипак, будући да само значење основне речи указује на хабитуалност употребе, одлучено је да консеквентно више одговара поткатегорији (б). Код примера (10) сам контекст јасније одређује семантичко пуњење као одговарајуће нашој категорији (б).

(9) Vedete fil filo va la cosa; chi legge quella comedia impara tutti i motti e tutti i garbetti fiorentini, impara a vivere e a lasciar vivere. Volete voi altro, che s'è cavata la maschera? Le stampe non ciufferanno già quella. (Anton Francesco Doni, I marmi, III, 50)

(10) Io non credo che in tutta Italia sia il più dolce passatempo di questo: qua ci vien musici, qua poeti, qua matti, qua si ragunan savi; qui si dice de' garbetti, ci si contan delle novelle, si dà la baia a chi la teme e si dice tutte le nuove del mondo. (Anton Francesco Doni, I marmi, III, 1)

У поткатегорију саосећајности (в) сврставају се примери чија конотација указује на емпатију или саосећање, о чему сведоче примери (11) и (12). Приметно је да се често јављају код именица које већ имају релативно нега-

${ }^{33}$ Maïa Ponsonnet, "A preliminary typology of emotional connotations in morphological diminutives and augmentatives", нав. дело, стр. 21.

${ }^{34}$ Claudio Marazzini, La storia della lingua italiana attraverso $i$ testi, Bologna, Il mulino, 2006, стр. 115. 
Данијела Ђоровић, Слађана Станојевић, Семантичке вредности деминутива ...

тивно значење. Такође, у приближној мери заступљени су у нашем корпусу и женски и мушки референти, иако се на основу књижевно-културолошких фактора могло очекивати да ће већи број примера бити у женском роду.

(11) Ora, menando questa vita Guglielmo, accadde che una sera, avendo egli con certi suoi amici cenato fuor di casa sua, nel tornarsene poi, sendo di notte un buon pezzo e buio come in gola, fu - o per malevoglienza, o còlto in cambio -, affrontato e ferito d'un pugnale sopra la poppa manca: onde il poverello, sentitosi ferito, si misse a fuggire. (Anton Francesco Grazzini detto il Lasca, Le Cene, I, 5, 4)

(12) Io so di chi voi dite. E la fa, perché gli è stato dato da intendere a la semplicella ch'ella faccia professione di esser di poco assetto e trascurata de la persona sua; tal che la poveretta, credendosi che sia bene, va fuora il più de le volte con gli occhi appicciati, che non si è pur lavato il viso con acqua chiara. (Alessandro Piccolomini, Dialogo della bella creanza delle donne, detto la Raffaella, 184)

Поткатегорија дивљења (г) обухвата примере деминутива уроњене у контекст истакнутог одобравања, као у примеру (13). Треба нагласити да се и у оквирима ове семантичке поткатегорије, одређене примесе значења могу протумачити као блиске поткатегорији привржености, али је афективност говорника у овом случају генерално усмерена на резултат интелектуалног или креативног рада.

(13) Io non credo che si possi far meglio di queste due comediette; le sono una gioia. Il Machiavello e Giovan Maria mi posson comandare. (Anton Francesco Doni, I marmi, IV, 25)

Посебно занимљива јесте употреба деминутива са примесама поменутог значења код Вазарија, у чувеној студији Животи славних сликара, вајара и архитеката у примерима (14) и (15), где се због природе текста не би ни очекивала њихова изразита заступљеност, али их аутор употребљава релативно често, и, по нашем мишљењу, релативно арбитрарно. Њихово значење, неодвојиво од амбијента историје и теорије уметности, могло би се потенцијално повезати с вредношћу објеката на које указују и упутити на минуциозност и квалитет уметничке израде.

(14) Nel tramezzo della chiesa in detto luogo è appoggiata una tavolina a tempera, dipinta di mano di Giotto con infinita diligenza e con disegno e vivacità dentrovi la Morte di Nostra Donna, con gli Apostoli che fanno l'essequie, e Cristo che l'anima in braccio tiene (Giorgio Vasari, Vite de' più eccellenti pittori, scultori ed architettori, III, 9)

(15) Fu condotto ad Ascesi a finir l'opera cominciata da Cimabue, dove passando da Arezzo lavorò nella pieve la cappella di San Francesco sopra il battesimo et in una colonna tonda, vicino a un capitello corinzio antico bellissimo, dipinse un San Francesco e San Domenico. Al duomo fuor d'Arezzo una cappelluccia, dentrovi la 
Lapidazione di Santo Stefano con bel componimento di figure. (Giorgio Vasari, Vite de' più eccellenti pittori, scultori ed architettori, Giotto)

Као што се може видети из ова два примера, тешко је у потпуности разлучити да ли је реч о денотативном или конотативном значењу, премда су намеру која се крије иза употребе деминутива препознали и српски и енглески преводиоци Вазаријевог дела, који су дате примере доследно превели деминутивима, односно изразима са деминутивним значењем. За пример (15) семантичка анализа још је компликованија, будући да се реч cappelluccia, врло често у дијахроном контексту употребљава са негативном конотацијом, како Томазео ${ }^{35}$ у свом речнику запажа: “una cappella meschina la chiamerei cappelluccia [...] per indicare un benefiziuccio assai magro il nome di cappelluccia mi parrebbe opportuno".

У оквиру макрокатегорије негативних значења, истичу се она већег и мањег интензитета. И док су присутна и мање интензивна значења ублажавања, што се може уочити у примерима (16) и (17) или задиркивања, примарно јесте значење неодобравања, као у примерима (18) и (19). Неодобравање даље може указивати на недостатак поштовања и може бити интензивирано до потцењивања и презира, што се запажа у примерима (20) и (21).

(16) E questo ti sia in risposta, senza ch'io più tel replichi, a tutte quelle cose che io ti dirò, le quali ti parrà che pizzichino alquanto di peccatuzzo. (Alessandro Piccolomini, Dialogo della bella creanza delle donne, detto la Raffaella, 61)

(17) E perch'egli era scaltro e maliziosetto, gli cadde nell'animo di tentare una via da dovergli agevolmente riuscire, per contentar i desideri suoi; e un lunedì in su le ventiun ora, travestitosi a guisa di villano, sparpagliatosi la barba, con una cuffia bianca e un cappelletto di paglia in testa, preso un bello e grasso papero in collo, nascosamente si partì di casa, e per tragetti se ne venne alla strada, poco di sopra al Portico. (Anton Francesco Grazzini detto il Lasca, Le Cene, I, 6, 4)

(18) Io non vo' ragionare de' Papi o de' Cardinali, né de' preti e manco de' frati: ché tu non mi appiccassi di subito il sonaglio ch'io fussi luterano; ma poni un po' mente a' fanciulletti di dieci anni, come sono senza reverenzia, senza vergogna, audaci, disonesti, e rivenderebbono un uomo di cinquanta. (Giovan Battista Gelli, Ragionamenti di Giusto bottaio, IV, 33)

(19) A questo romito venerabile pose lo animo la moglie del dottore, che allora procurava nella città per le liti di molti; e gli facea di gran carità; e spesso se ne andava allo ermo suo certamente divoto e dilettevole, donde riportava alcune insalatucce amare facendosi coscienza di assaggiare delle dolci. (Pietro Aretino, Ragionamento, II, 34)

(20) Sapete quanti capi, quanti parentadi intratenevano nel Dominio per potersene servire a' bisogni, cioè per avere forze da tenere soffocati i cittadini: a tutti questi

${ }^{35}$ Niccolò Tommaseo, Nuovo dizionario de'sinonimi della lingua italiana, Gammella e Festa, 1838, стр. 87. 
Данијела Ђоровић, Слађана Станојевић, Семантичке вредности деминутива ...

si conveniva avere rispetto, ed a' parenti ed amici e partigiani di questi. Il medesimo dico in Firenze; e per questa ragione non solo si procedeva spesso dolcemente contro alle ferite e l'altre violenzie, ma si tollerava che i nostri cittadini o questi tirannelli di fuora usurpavano i beni de' vicini, degli spedali, delle communità e delle chiese. (Francesco Guicciardini, Dialogo del reggimento di Firenze, 34)

(21) O - diss'io - canaglia mondana, che credete, con quattro letteruccie stitiche, sapere ogni cosa e a pena siate fuori delle pezze! o animaletti studiantuzzi che scacazzate con duoi pigrammi uno stracciafoglio e credete d'esser tenuti i savi della villa! o imbrattamestieri che rappezzate scartabegli, andatevi a ficcare in un cesso! o poetuzzi che fate le vostre leggende da un soldo e poi volete il capo infrascato, frasche veramente siete, civettini. Non udite voi che '1 Tempo è quel che sa? Non bisogna, per fare l' altiero, il signorotto e il nobile, furfantegli, figliuoli di spadai, di notaiuzzi, di montanari e di fanti, sputar sì tondo! (Anton Francesco Doni, Ragionamento IV, 51)

Велики дијапазон значења која носе негативну ноту одликује пре свега разлика у интензитету негативних значења. Она могу ићи од шаљивог, благо негативног, задиркивања до дубоког презира који означава крајњу тачку негативно конотираног значења. Ту велику разлику у интензитету, која није тако евидентна нити типична за позитивно обележене семантичке вредности, пригодно илуструју примери (22) и (23), од којих први поседује јасно значење потцењивања, док други указује на примесе семантичке вредности задиркивања.

(22) E questa pienezza importa assai, perché non si vede mai peggio che quando noi vediamo alcune de le nostre gentildonne, che vanno per Siena con certe vestarelle che non v'è dentro sedeci brazza di drappo, con le loro sberniette, che non gli arrivano al culo a una spanna, e, aggirandosene una parte al collo e tenendone un lembo in mano, col quale si copron mezzo il viso, e' van facendo le mascare per la strada; e, con l'altra mano alzandosi la veste di dietro, accioché non si logori toccando terra, vanno per la strada con una certa furia, con un tric trac di pianellette, che par che gli abbino il diavolo fra le gambe.

(23) Vero è che le calze toglievano di biasimo la palandrana: elle erano state di rose secche, ma non erano più; e attaccate al farsetto con duo pezzi di stringhe sanza puntali, gli campeggiavano in gamba a modo di calzoni da galeotti; e facea bel vedere un calcagnetto che gli scappava finora della scarpa al dispetto del suo dito che a ogni passo lo rispingeva dentro. (Pietro Aretino, Ragionamenti, II, 42)

Пример (23) нарочито је интересантан, и то са гледишта дијахроније, будући да Кастелани тврди да је реч scarpetta заправо ушла у италијански језик из византијског грчког пре речи scarpa и са значењем које ће она касније преузети. ${ }^{36}$ Ипак, њено деминутивно значење до почетка 16. века већ је кристализовано.

${ }^{36}$ Arrigo Ettore Castellani, Grammatica storica della lingua italiana: Introduzione, Bologna, Il Mulino, 2000, стр. 211-212. 
Кад је реч о полу референата код овако семантички обојених деминутива, књижевно-историјска традиција и познавање културног контекста епоха у којима су дела настала навели су нас на претпоставку да ће евалуативни суфикси попримити значење мањег или већег степена потцењивања превасходно у примерима који се односе на женске референте. У овом смислу, наша хипотеза је потврђена у примерима из корпуса, од којих два наводимо у наставку.

(24) Onde egli si legge di Teofrasto, che fu l'un de' lumi della greca eloquenzia, essendo in Atene, alle parole essere stato giudicato forestiere da una povera feminetta di contado (Sperone Speroni, Dialogo delle lingue).

(25) Egli si stava suso uno monticello rilevato, e gli avea posto nome "il Calvario", in mezzo del quale era un crocione con tre chiodacci di legname che impaurivano le donnicciuole: e detta croce tenea al collo la corona di spine, e nelle braccia due sferze pendenti di corda annodate, e nel piede una testa di morto. (Pietro Aretino, Ragionamenti, II, 36)

Док је коришћење деминутива лексема које означавају младунчад претходно разматрано у контексту привржености, примери из корпуса потврђују да се исти тип деминутива могао употребити и у сасвим супротном контексту, са сврхом изражавања ниподаштавања, дакле у домену негативних значења о чему сведочи пример (26).

(26) E sì come, per parere degli astronomi, il Sole, signor delle stelle, non va per lo cielo senza la compagnia di Mercurio, così il marito, signor della moglie, non dee essercitare il suo imperio senza la compagnia della sapienza, ma rivolger nell'animo che la moglie, non altrimente che pecorella, s'ammorba spesso per negligenza del pastore, cioè del marito. (Stefano Guazzo, La civil conversazione, III)

Иако се за идеју деце уобичајено везују позитивна конотативна значења, у нашем корпусу забележено је и неколико примера деминутива који сведоче да је могуће да се у амбијенту одраслих оно што је дечије опажа као мање вредно, као негативно. Један од таквих је и пример који следи:

(27) Ohimè! che dolor credi tu. Giusto, che sia stato il mio, che son sì nobile creatura, ne lo aver sempre a ministrarti ogni mio sapere e ogni mia possanza perché tu facci botti, bigonciuoli, arcucci da bambini, zoccoli, e altre simil cose vili? e che solamente per i bisogni tuoi abbia avuto a lasciare la contemplazione della bellezza di questo universo, e a tener gli occhi rivolti in giù in cosa tanto bassa e contro a la natura mia? Dimmi un poco: non ho io ragione di dolermi? (Giovan Battista Gelli, Ragionamenti di Giusto bottaio, III, 37)

Семантичка вредност деминутива битно је обележена намером корисника, контекстом у којем се употребљава, конвенцијама писаног или гово- 
Данијела Ђоровић, Слађана Станојевић, Семантичке вредности деминутива ...

реног дискурса у оквиру којег се јавља. Свака класификација стога нужно има своја ограничења и дозу арбитрарности. Категорије и поткатегорије осмишљене и описане у овом раду у том смислу нису и не могу бити изузетак. Класификовање више ексцерпираних примера представљало је значајне потешкоће, а то се најбоље може разумети уколико се размотре примери у којима је очигледно било преливање поткатегорија и немогућност да се са сигурношћу утврди која је преовлађујућа. За свих пет примера деминутива који следе могло би се рећи да поседују вредност потцењивања, али, поред њега, примери (28) и (29) евидентно носе и примесе значења ублажавања. Пример (30) могао би се протумачити такође и у контексту романтичне љубави, док се примери (31) и (32) одликују вредношћу привржености.

(28) E vestite che furo, Antonia fece, inanzi che le campanelle, sonassero, tutte quelle faccendette che alla Nanna mettevano più pensiere che non mette la sua fabrica a san Pietro. (Pietro Aretino, Ragionamenti, II, 1)

(29) Ora la prima cosa, figliuola, tu hai da por cura che quei piaceri, i quali conchiuderemo oggi che ti si convenghino, tu vegga di pigliarteli con tale ingegno e con tal arte, che il tuo marito più presto abbia da comportarlo volentieri che da pigliar un minimo sospettuzzo de' casi tuoi. (Alessandro Piccolomini, Dialogo della bella creanza delle donne, detto la Raffaella, 83)

(30) Un pastorello e una semplice pastorella essendosi da lungo amati vengono ad efetto del loro amore. (Pietro Fortini, Le Giornate delle novelle dei novizi, 12, 1)

(31) Continovando Cassandrino in tal maniera le sue parole, ecco che il cherichetto uscì fuori di sacrestia (Giovan Francesco Straparola, Piacevoli notti, I, 2, 7)

(32) E Guglielmo, cavato di quella volta, fecero sotterrare in sagrato, con meraviglia e stupore grandissimo di chiunque lo vide; e senza indugio mandarano in villa a pigliare la possessione de i poderi, dove fu cacciato ognuno fuori; e la Maddalena e la madre se ne tornarano in Pisa alla loro casetta povere e sconsolate. La Pippa, sendo stata licenziata, se ne tornò verso casa, credendosi, come prima, essere la bella madonna; ma di gran lunga ne rimase ingannata, perché le fantesche, i servidori e i figliolini trovò fuori dalla famiglia della corte essere stati cacciati: onde con essi, dolorosa a morte, nella sua vòta casa se ne entrò, tardi piangendo e dolendosi, accorta del suo errore. (Anton Francesco Grazzini detto il Lasca, Le Cene, I, 5, 23)

Оно што додатно отежава овакво истраживање јесте и значајан уплив субјективности и личног књижевног печата који носи сваки од ауторских текстова из којих су црпљени примери, те је сваки покушај уопштавања и тражења заједничког именитеља често упитан. Ипак, сваки, па макар и најмањи, увид у семантичке вредности деминутива коришћених у специфичном моменту развоја италијанске књижевности и њеног језичког израза обогаћује наша сазнања о овом важном и истраживања вредном феномену морфосемантике сваког, а нарочито италијанског језика. 


\section{5. Закључак}

Међу конотативним значењима деминутива приметна је тенденција да преовлађују они са позитивним вредностима, ${ }^{37}$ што је потврђено и у овом истраживању, премда је забележен и немали број примера са негативним конотацијама. Категорије деминутива заступљене у нашем корпусу поклапају се у знатној мери са онима присутним у претходним истраживањима деминутива на синхронијској и дијахронијској равни. Међутим, поједине категорије познате из ранијих истраживања у овом корпусу нису забележене. Разлог томе може бити скуп текстова које је корпус MIDIA изабрао као репрезентативне за испитивани период, који је генерално намењен морфолошким истраживањима, али не неопходно конкретном истраживању евалуативних афикса.

Као што је и очекивано после увида у доступну литературу, посебан изазов у истраживању представљало је сврставање пронађених примера у одговарајуће категорије и одређивање њихове прецизне дефиниције. Интерпретација одређених примера нужно је била арбитрарна, будући да референтна дијахронијска литература не постоји, док је за друге примере потврда наше интерпретације пронађена у историјским граматикама које се, бар у појединим случајевима и у одређеној мери, дотичу овог проблема.

Због природе самих текстова који у већој мери изражавају субјективни став аутора у односу на неконтекстуализоване примере који се најчешће јављају у истраживањима овог типа, у обзир је морао бити узет и сегмент личних преференција појединачних писаца. ${ }^{38}$ Стога не изненађује да се одређене категорије деминутива доследније јављају код појединих аутора, док су код других ретке или готово у потпуности изостају.

Претензија овог рада није био свеобухватни приказ разноврсних семантичких вредности италијанских деминутива у историјско-књижевном контексту, већ покушај примене сазнања из ове области на до сада недовољно истражени дијахронијски контекст употребе евалуативних афикса. Како би се стекло потпуније разумевање овог комплексног питања, неопходно би било допунити налазе овог истраживања одговарајућим испитивањима семантичке природе деминутива у италијанском књижевном језику других епоха, нарочито оних које непосредно следе или претходе периоду истраженом у овом раду.

${ }^{37}$ Maïa Ponsonnet, "A preliminary typology of emotional connotations in morphological diminutives and augmentatives", нав. дело, стр. 11; Grazia Crocco Galèas, "Diminutives within the theory of morphopragmatics", нав. дело, стр. 10.

${ }^{38}$ Bruno Migliorini, Storia della lingua italiana, Sansoni, 1988, стр. 274 
Данијела Ђоровић, Слађана Станојевић, Семантичке вредности деминутива ...

\section{ЛИТЕРАТУРА}

Biały, Paulina, "On the priority of connotative over denotative meanings in Polish diminutives", Studies in Polish Linguistics, 8 (1), 2013, pp. 1-13.

Castellani, Arrigo Ettore, Grammatica storica della lingua italiana: Introduzione, Bologna, Il Mulino, 2000.

Coleridge, Herbert, "On diminutives in let”, Transactions of the Philological Society, 4 (1), 1857, pp. 93-115.

Dardano, Maurizio, Trifone, Pietro, La lingua italiana, Zanichelli, 1985.

Dossena, Marina, "Vocative and diminutive forms in Robert Louis Stevenson's fiction: A corpus-based study". Journal of English Studies, 12 (2), 2012, pp. 1-17.

Dressler, Wolfgang U., Merlini Barbaresi, Lavinia, "Italian Diminutives as Non-Prototypical Word Formation", Natural Morphology-Perspectives for the Nineties, 1992, pp. 21-29.

Dressler, Wolfgang U., Merlini Barbaresi, Lavinia, Morphopragmatics: diminutives and intensifiers in Italian, German, and other Languages, BerlinNew York, Mouton, 1994.

Galèas, Grazia Crocco, "Diminutives within the theory of morphopragmatics", Working Papers in Linguistics, Thessaloniki, Aristotle University, 2004, pp. 9-18

Grandi, Nicola, "Matrici tipologiche vs. tendenze areali nel mutamento morfologico. La genesi della morfologia valutativa in prospettiva interlinguistica", Lingue e linguaggio, 2 (1), 2003, pp. 105-146.

Grandi, Nicola, The place of evaluation within morphology. Edinburgh handbook of evaluative morphology, 2015, pp. 75-90.

Haas, Mary R., "The Expression of the Diminutive". In DIL, A. S. (ed.). Language, culture and history: essays by Mary R. Haas, Stanford, Stanford University Press, 1978, pp. 82-88.

Jurafsky, Dan, "Universal tendencies in the semantics of the diminutive", Language, 1996, pp. 533-578.

Lewis, George Cornewall, On English Diminutives, The Philological Museum, 1832, pp. 679-86.

Marazzini, Claudio, La storia della lingua italiana attraverso i testi, Bologna, Il mulino, 2006.

Migliorini, Bruno, Storia della lingua italiana, Sansoni, 1988.

Munro, Pamela, "Diminutive syntax", In W. Miller (ed.), A Festschrift for Mary R. Haas, The Hague, Mouton, 1988, pp. 539-56

Náñez Fernández, Emilio, El diminutivo. Historia y funciones en el español clásico y moderno. Madrid: Editorial Gredos, S. A., 1973.

Ponsonnet, Maïa, "A preliminary typology of emotional connotations in morphological diminutives and augmentatives", Studies in Language. 
International Journal sponsored by the Foundation "Foundations of Language", 42(1), 2018, pp. 17-50.

Reber, Artur, Reber, Emili, Rečnik psihologije, Beograd, Službeni glasnik, 2010 .

Rohlfs, Gerhard, Grammatica storica dell'italiano e dei suoi dialetti, vol. II, Sintassi e formazione delle parole, Torino, Einaudi, 1969.

Salvi, Giampaolo, Renzi, Lorenzo, Grammatica dell'italiano antico, Bologna, Il mulino, 2010.

Scalise, Sergio, Generative morphology, Dordrecht, Foris, 1984.

Schneider, Klaus P., "The truth about diminutives, and how we can find it: Some theoretical and methodological considerations", SKASE Journal of Theoretical Linguistics, 10(1), 2013.

Spitzer, Leo, Italienische Kriegsgefangenenbriefe: Materialien zu einer Charakteristik der volkstümlichen italienischen Korrespondenz, P. Hanstein, 1921.

Steriopolo, Olga, "Form and function of expressive morphology: A case study of Russian". In Russian Language Journal, 2009, vol. 59, pp. 149-194

Tommaseo, Niccolò, Nuovo dizionario de'sinonimi della lingua italiana, Gammella e Festa, 1838.

Volek, Bronislava, Emotive signs in language and semantic functioning of derived nouns in Russian. Amsterdam, J. Benjamins, 1987.

Wierzbicka, Anna, "Diminutives and depreciatives: Semantic representation for derivational categories", Quaderni di semantica, 5(1), 1984, pp. 123-30.

Николић, Мирослав, (ур.), Речник српскога језика, Нови Сад, Матица српска, 2011.

Самарџић, Мила, Поглед на речи, Београд, Филолошки факултет Универзитета у Београду, 2011.

Danijela Đorović

Slađana Stanojević

\section{SEMANTIC VALUES OF DIMINUTIVES IN LITERARY TEXTS \\ OF THE ITALIAN RENAISSANCE AND BAROQUE \\ (Summary)}

The rich and varied system of diminutives in Italian is well-known for its productivity and complexity. Consequently, it has triggered research interest in a variety of studies within linguistics and pragmatics. Unlike numerous works dealing with the issue from a synchronic perspective and with respect to non-literary material, this paper investigates semantic values of diminutives used in the Italian literary language of Renaissance, Mannerism and Baroque with the help of MIDIA corpus (a balanced diachronic corpus of written Italian texts ranging from the $13^{\text {th }}$ to the first half of the $20^{\text {th }}$ century). The results of the research show that diminutives in question can hardly ever be interpreted 
Данијела Ђоровић, Слађана Станојевић, Семантичке вредности деминутива ...

as predominantly denotative in meaning. A number of different connotative and associative semantic components have been detected instead, stemming from various positive or negative evaluative judgments ranging from adoration to contempt.

Keywords: diminutives, semantic values, evaluative morphology, connotative meanings, Italian language

Примљено 29. новембра 2019, прихваћено за објављивање 10. децембра 2020. године. 